\title{
Resettlement's Renaissance: A Cautionary Advocacy
}

\author{
Shauna Labman
}

\begin{abstract}
Arising out of UNHCR's Global Consultations was a renewed emphasis on the role of resettlement as a protection tool, durable solution, and burden-sharing mechanism. Resettlement is a useful instrument for all three reasons enumerated by UNHCR. Its malleability, however, also makes it prone to manipulation. It can be, and has been, used by states to obfuscate an unwillingness to meet their international legal obligations through a replacement of refugee protection by migrant selection. The argument is made here for why resettlement is a necessary component of refugee protection, particularly in the current period of securitization following the events of 11 September 2001. This is followed by a discussion of the dangers of the abusive use of resettlement to the overall refugee protection scheme. Models for more structured resettlement are examined with a view to understanding what reform is needed. In conclusion, recommendations for resettlement reform are provided.
\end{abstract}

\section{Résumé}

Suite aux Consultations mondiales du HCR, on a assisté à un regain d'emphase sur la réinstallation comme instrument de protection, comme solution durable et comme mécanisme de partage international de la charge. La réinstallation est un instrument utile pour chacune des trois raisons énumérées par le HCR. Cependant, sa malléabilité la rend aussi susceptible à la manipulation. Elle peut-et cela a déjà été le cas-être utilisée par certains états pour dissimuler leur réticence à honorer leurs engagements légaux internationaux en substituant la sélection des migrants à la protection des réfugiés. L'article met de l'avant des arguments démontrant pourquoi la réinstallation est un élément essentiel pour la protection des réfugiés, en particulier en la présente période de "sécurisation "suivant les événements du 11 septembre 2001. Une discussion s'ensuit sur les dangers de l'utilisation abusive de la réinstallation au détriment du cadre global de protection des réfugiés. Pour conclure, des modèles de réinstallation plus structurée sont examinés dans le but de déterminer les réformes requises.

$\Delta$ refugee, by definition, is an individual who has fled his or her homeland on the basis of a well-founded of persecution on account of race, religion, nationality, membership in a particular social group, or political opinion. ${ }^{1}$ While the refugee definition applies equally to all who are found to meet it, the protection attached to refugee status can differ greatly. Protection ranges from new citizenship to crowded camps. The determining factor is where refugee status is claimed. The Convention relating to the Status of Refugees (Refugee Convention) obliges signatory states to not refoule refugees who have arrived within the state's territory. ${ }^{2}$ While signatory states grant refugee status and sometimes citizenship to the refugees who reach their shores, other states, often overwhelmed by refugees and determined to discourage further flows, have not signed the Refugee Convention.

In signatory states, refugee protection is conferred under domestic legislation once the state determines that an individual meets the refugee definition. In non-signatory states that lack similar refugee laws or status determination procedures, the United Nations High Commissioner for Refugees (UNHCR) may grant mandate refugee status under the Statute of the United Nations High Commissioner for Refugees. ${ }^{3}$ UNHCR then seeks "durable solutions" for refugees. Durable solutions comprise local integration in the receiving country, voluntary repatriation to one's country of origin where the situation has changed so as to make this a possibility, or resettlement to another country. ${ }^{4}$ Where 
neither local integration nor repatriation is possible, resettlement is the only option.

Resettlement requires a third country to be willing to accept refugees into its territory. While signatory states to the Refugee Convention have promised not to refoule asylum seekers at their borders, they have not committed to accept refugees for resettlement. Too many of the world's refugees are therefore left to linger in non-durable conditions in countries of first asylum that are often only minimally safer than the countries they have fled. This article provides an examination of resettlement and an argument for its increased use as a tool of protection and responsibility-sharing while also warning against resettlement's vulnerability to manipulation.

\section{Resettlement}

As it approached its fiftieth anniversary in 2001, UNHCR was in the midst of an identity crisis. States that were the very authors of the Refugee Convention were vocally challenging its continued relevance and surreptitiously evading their obligations. ${ }^{5}$ In both response to the crisis and in celebration of the anniversary, UNHCR initiated the Global Consultations on International Protection (Global Consultations) to address the situation through ministerial meetings, expert roundtables, and policy formulation. ${ }^{6}$ One of the key developments to arise out of the resulting Agenda for Protection was a renewed emphasis on the role of resettlement. ${ }^{7}$

Resettlement is defined by UNHCR as "the selection and transfer of refugees from a State in which they have sought protection to a third State which has agreed to admit them - as refugees - with permanent residence status." 8 The decision to resettle a refugee is only made in the absence of other options - local integration or repatriation. ${ }^{9}$ There is an undercurrent of debate as to whether resettled refugees should be granted permanent residence. ${ }^{10}$ Nor does refugee resettlement only occur through arrangements between UNHCR and states. It can also occur in certain countries through referrals from organizations other than UNHCR or through private sponsorship by an organization or individual of the third state. This article, however, is confined to a consideration of "government-assisted"11 permanent resettlement through UNHCR.

Resettlement has a checkered past that predates the Refugee Convention. The International Refugee Organization, established in 1946, resettled over 1 million refugees between 1947 and 1951. ${ }^{12}$ In fact, resettlement was the tool of choice of all refugee organizations that preceded UNHCR. ${ }^{13}$ James Hathaway notes there was an assumption during this earlier period that "there was little likelihood that refugees would be accommodated in the first asylum country." 14 As enshrined in Article 33(1), the Refugee Con- vention shifted the focus of refugee protection to the principle of non-refoulement. The boat people crisis of the 1970s and early 1980s brought a resurgence in resettlement enthusiasm with 1.2 million Indo-Chinese resettled by UNHCR between 1976 and 1989. Gary Troeller, a UNHCR representative, reports that by the late 1970s UNHCR was involved in the resettlement of 200,000 persons per year, and that at one point in 1979 "resettlement was viewed as the only viable solution for 1 in 20 of the global refugee population under the responsibility of UNHCR." 15 Beginning in the late 1980s however, resettlement came to be viewed by UNHCR as the least preferred durable solution. Concerns that large-scale resettlement was leading to the abandonment of asylum in first countries and serving as a pull factor for individuals to leave home for social and economic reasons, combined with an increased emphasis on voluntary repatriation following the end of the Cold War, limited enthusiasm for resettlement. ${ }^{16}$ By 1996 UNHCR resettled only 1 in every 400 of the global refugee population under its care. ${ }^{17}$

In its current reinvigorated state, UNHCR has proclaimed that resettlement "serves three equally important functions:"

First, it is a tool to provide international protection and meet the special needs of individual refugees whose life, liberty, safety, health or other fundamental rights are at risk in the country where they have sought refuge. Second, it is a durable solution for larger numbers or groups of refugees, alongside the other durable solutions of voluntary repatriation and local integration. Third, it can be a tangible expression of international solidarity and a responsibility sharing mechanism, allowing States to help share each other's burdens, and reduce problems impacting the country of first asylum."18

While the re-emergence of resettlement discourse is to be applauded, the difficulty with UNHCR's current tripartite construction is that it risks sending resettlement into its own dizzyingly schizophrenic identity crisis - uncertain of how to actualize its role in an effective manner.

Resettlement is a useful tool for all three reasons enumerated by UNHCR. Its malleability, however, also makes it prone to manipulation. It can be, and has been, used by states to obfuscate an unwillingness to meet their legal obligations under the Refugee Convention through a replacement of refugee protection by migrant selection. What follows can best be termed "cautionary advocacy." The argument is first made that resettlement is a necessary component of refugee protection, particularly in the current period of securitization following the events of 11 September 2001. This section is followed by a discussion of 
the dangers of the abusive use of resettlement to the overall refugee protection scheme. Models for more structured resettlement are then examined with a view to at least understanding what reform is needed. In conclusion, recommendations for resettlement reform are provided.

\section{Why Resettlement?}

UNHCR reported that by the end of 2005 the global number of refugees was an estimated 8.7 million persons. ${ }^{19}$ One in four of these refugees, 24 per cent, are in either Pakistan or the Islamic Republic of Iran. ${ }^{20}$ In total, by UNHCR bureau divisions, over 2.5 million refugees are hosted in Africa, excluding North Africa, and almost another 2.5 million are in CASWANAME, UNHCR's bureau encompassing Central Asia, South West Asia, North Africa, and the Middle East. Europe hosts just under 2.0 million refugees and there are over 800,000 in Asia and the Pacific. In the Americas, in total, there are fewer than 600,000 refugees. ${ }^{21}$ The numbers highlight "that refugees and mass movements are first and foremost a "developing country" problem and that the biggest "donors" are in reality developing countries who put at risk their fragile environment, economy, and society to provide refuge to millions."22 Matthew Gibney terms this uneven distribution the "tyranny of geography." ${ }^{23}$ In somewhat more neutral parlance, it raises the issue of burden sharing. ${ }^{24}$ Following a review of the asylum policies of the US, Germany, the UK, and Australia, Gibney writes:

...the limitations of the current international response are rooted in the fact that states have failed to agree upon fair terms for the distribution of responsibility for refugees (resulting in huge inequalities in state burdens) and that most states are content to 'free ride' off countries that have more inclusive asylum policies... ${ }^{25}$

In addition to more inclusive policies, or conversely less forceful interdiction, the "tyranny of geography" can be taken to convey that certain countries, particularly those in Africa, Asia, and the Middle East are simply closer to and more easily accessed by refugee flows.

The Refugee Convention acknowledges the need for burden sharing, considering in its Preamble "that the grant of asylum may place unduly heavy burdens on certain countries, and that a satisfactory solution of a problem of which the United Nations has recognized the international scope and nature cannot therefore be achieved without international co-operation." 26 There is no further mention of burden sharing in the Refugee Convention or in the subsequent 1967 Protocol relating to the Status of Refugees (1967 Proto$\mathrm{col}) .{ }^{27}$ Resettlement is by no means the only form of burden sharing. Many countries also make significant financial contributions to refugee receiving countries and UNHCR. ${ }^{28}$ One controversial argument by Peter Schuck, for instance, recommends that all non-refugee producing states be allocated a yearly quota of refugees for care or resettlement that they can either absorb themselves or pay another country to provide surrogate care. ${ }^{29}$ Goal 3(6) of UNHCR's Agenda for Protection, however, outlines the significant role of resettlement in burden sharing:

3(6): Resettlement used more effectively as a tool of burdensharing.

- States to examine how more flexible resettlement criteria could be applied with regard to refugees recognized on a prima facie basis in mass displacement situations to whom Article $1 \mathrm{~F}$ does not apply, coupled with, as appropriate, temporary humanitarian evacuation programmes.

- The Working Group on Resettlement to examine further the potential use of resettlement as a burden-sharing tool, which would include the issue of criteria to be applied in mass displacement situations, especially where the prospect of other durable solutions is remote or absent. ${ }^{30}$

As of 1 March 2006, there were 147 states party to the Refugee Convention or 1967 Protocol or both. ${ }^{31}$ Stretching to the smallest numbers, there are a mere sixteen resettlement countries with yearly resettlement numbers ranging from 53,813 in the US to 29 in Mexico. ${ }^{32}$ Gil Loescher and James Milner note:

[t] he overwhelming majority of long-term refugees could be eligible for resettlement, but a lack of resettlement opportunities, of resettlement staff to prepare submissions, and inefficiencies in the process of preparing and submitting resettlement cases have resulted in the under-utilisation of this durable solution. $^{33}$

In its current incarnation, resettlement is not an effective tool of burden sharing.

The argument for resettlement is difficult. Not because the image of wasted lives in limbo is not compelling but because it is not seen. It is as if the refugees have been rendered invisible. Bill Frelick offers the following description of the reality for these individuals:

Millions of refugees worldwide have been relegated to a limbo existence, warehoused in camps or settlements with no prospects for voluntary repatriation or local integration. Children born and raised within the confines of camps often never see normal life outside the fences. These populations often become 
dependent and despondent, with predictably negative social consequence. $^{34}$

Highlighting the refugee's invisibility, Jennifer Hyndman argues that camps "remove evidence of human displacement from view and contain 'the problem' without resolution, as noncommunities of the excluded." 35

For those left in the camps, rural outskirts, or apartment complexes in urban corners, there is the assumption that while not receiving government protection, refugees are nonetheless within UNHCR's protective bubble. To an extent this assumption is true. These refugees are recognized by UNHCR and receive protection under its mandate. UNHCR is able to offer basic aid and assistance. As Loescher explains: "UNHCR is identified primarily with assistance - the delivery of food, shelter, and medicine - to refugees and war-affected populations." 36 Hyndman notes, though, that "UNHCR is careful not to make the camps too attractive to potential refugees or other migrants by maintaining minimum educational and other facilities, an approach that has been called 'humane deterrence."'37

While a comfortable camp environment and the chance at resettlement risk serving as pull factors that encourage migrant flows, these concerns are muted by the reality of UNHCR's powerlessness in the camp setting. Loescher indicates:

The central importance of human rights protection of displaced and threatened populations is frequently neglected. [...] While UNHCR and other humanitarian organizations are able to deliver large quantities of humanitarian supplies under extremely difficult conditions, they are much less successful in protecting civilians from human rights abuses... ${ }^{38}$

He adds, "host governments or dissident warlords ultimately exercise control over the agency's operational environment." 39 In the chapter that follows Loescher's article, Arthur Helton recalls the image of soldiers from the "benign refugee-hosting state" of Tanzania marching Rwandan refugees back across the border at gunpoint in December $1996 .{ }^{40}$

Beyond invisibility, the primary difficulty with resettlement is that it is undertaken by states on an entirely voluntary basis. Unlike the obligation on all signatory countries not to refoule refugees at their borders, there is no requirement that signatory states bring refugees to their borders. As Janet Dench notes, "[i]nstead of addressing how people fleeing persecution might seek asylum in other countries, the Refugee Convention relating to the Status of Refugees focused on the obligation of states not to refoule a refugee to persecution." ${ }^{41}$ The Refugee Convention is, therefore, reactive in its structure. Resettlement in contrast is in Hel- ton's terms a "proactive refugee policy." 42 A coherent and comprehensive refugee policy must be both proactive and reactive.

This is an important point to highlight. An argument for increased resettlement should not be interpreted as a criticism of the principle of non-refoulement or as an argument that it should be diminished in favour of increased resettlement. What must be acknowledged is that the current world climate means that there are increased obstacles to asylum seekers reaching safe countries on their own. In the introduction to UNHCR's Global Consultations the editors note that:

it has been noticeable that the post-September 11 context has been used to broaden the scope of provisions of the 1951 Convention allowing refugees to be excluded from refugee status and/or to be expelled. The degree of collaboration between immigration and asylum authorities and the intelligence and criminal law enforcement branches has also been stepped up. ${ }^{43}$

For Catherine Dauvergne, "[ $\mathrm{t}]$ he worldwide fear of terror has overlapped and intertwined with the fear of illegal migration." 44 Although intentions are difficult to gauge and may be overlapping, it can safely be said that in some circumstances refugees are being targeted for exclusion while in others they are the unintentional victims. I will deal with the latter argument first and the former below under the heading "Dangers of Abuse."

While Article 31 of the Refugee Convention prevents the imposition of penalties for illegal entry by asylum seekers, it does not and cannot prevent a country from deterring illegal entry - as this is, in many ways, the essence of statehood. ${ }^{45}$ Refugees inevitably travel within mixed migratory flows. ${ }^{46}$ There is no way in advance to decipher between legitimate refugees and economic migrants or even potential terrorists for that matter. While this does not legitimize the vilification of all migrants, it does pose a conundrum for refugee protection. UNHCR reports a measured decrease in the number of asylum claims registered in industrialized countries from 2004 to 2005 and links the reduction to "increasingly restrictive national asylum policies." 47

The intent of this article is neither to criticize nor support these policies although their recent explosion is remarkable. ${ }^{48}$ Rather, in the face of these policies, the argument is that increased resettlement makes particular sense. Troeller notes:

There is no necessary or proven correlation between increased resettlement and a reduction in the number of those legitimately or illegitimately seeking asylum. On the other hand, 
increased resettlement opportunities may reduce the motivation to move 'irregularly' in search of asylum. ${ }^{49}$

Further, as borders turn into barriers, legitimate asylum seekers are finding it more and more difficult to find the protection envisioned by the Refugee Convention. John Fredriksson, one of the few people writing directly on resettlement, has therefore argued that "[i]n the aftermath of the tragic events of 11 September, [resettlement] may prove to be one of the most useful tools in the protection kit." 50 Joanne van Selm similarly suggests the post-11 September security measures "could in fact benefit some of those people seeking asylum and refuge by ensuring other, safer, means of arrival, including the expansion of resettlement." 51

And indeed, according to Hathaway, there has been a "recent renaissance of interest by some governments" in resettlement schemes. ${ }^{52}$ The top three resettlement countries have traditionally been and continue to be the US, Australia, and Canada. ${ }^{53}$ In 2005, Australia and Canada each resettled approximately ten times the number of refugees as Sweden, the fourth largest resettlement country, and the US resettled more than fifty times Sweden's resettlement numbers. ${ }^{54}$ The issue, however, is whether resettlement is truly being used as a tool of protection or as a tool of selection and evasion - what non-governmental organizations (NGOs) have referred to as a "fig leaf for policies of migration control." 55

\section{Dangers of Abuse}

It is not within the scope of this article to provide a comprehensive review and analysis of the instances and structures of abuse that occur. Rather, what follows is a brief survey of the top three resettlement countries - Canada, the US, and Australia - and the difficulties with their current resettlement schemes. This is followed by a comment on the UK, which has recently initiated a resettlement program.56

Over the years the Canadian government has received pointed critiques that its resettlement program amounted to cherry-picking. ${ }^{57}$ With the enactment of the new Immigration and Refugee Protection Act (IRPA) in 2001, the Government of Canada claimed a shift in Canadian resettlement policy toward protection rather than ability to establish. ${ }^{58}$ Through regulations under IRPA, the "successful establishment" criterion that requires refugees to show that they have good settlement potential is now waived for refugees designated "vulnerable" or in "urgent need." 59 While a clear shift to need-based protection in theory, Michael Casasola notes that in the years preceding IRPA's enactment "the number of refugees facing urgent or emergency protection concerns [was] actually quite small." ${ }^{60} \mathrm{He}$ reports that in 1999 UNHCR referred only 114 urgent and emergency submissions across all resettlement countries. ${ }^{61}$ As the Canadian Council for Refugees (CCR) reported in its 2003 Report Card "[m] ost refugees seeking resettlement in Canada still need to meet the 'successful establishment' requirement, undermining the program's ability to offer protection to those in need." 62 CCR goes on to note, "Canada is the only resettlement country to formally exclude refugees from resettlement based on their integration potential." 63

At the same time, the threat, and even more, the fear of terrorism has enabled government justification and support for restrictive policies. IRPA now ties protection to proposals to be "tough on those who pose a threat to Canadian security." ${ }^{4}$ Reviewing the first incarnation of the legislation that eventually became IRPA, ${ }^{65}$ Casasola noted:

Unfortunately the most negative aspect of the legislative package was that the many positive resettlement initiatives were presented as a counter to some of the more punitive actions the government planned in order to limit access to the refugee determination system in Canada. In fact, the resettlement initiatives became an important part of the selling of the bill to the Canadian public. ... Resettled refugees were presented as part of the refugees using the 'front door.' And by providing refugees greater access, Canada suggested it had the moral authority to limit access to those refugees described as using the back door. $^{66}$

This desire for choice and control of refugee selection is further emphasized in the US and Australian resettlement schemes.

With respect to the US resettlement program, Gibney succinctly describes it as "generous but not humanitarian." ${ }^{27}$ Gibney traces the role of lobby groups and foreign policy considerations in determining the composition and character of resettled refugees. He notes that as a discretionary scheme "there has been no move in resettlement policy to correspond with an attempt to expunge political preferences from asylum processes..."68 Van Selm adds:

The US resettlement programme is used to giving a strong level of management, or the appearance thereof, to the arrival and situation of refugees in the United States. The United States has considerable power to choose which of the world's refugees become refugees in the United States, even if it is only selecting some 80,000 to 90,000 out of 20 million annually. The mere fact of such selection is linked not only to domestic policy concerns about the acceptability of certain groups of refugees or the appeal to public sympathies, but also to foreign policy concerns expressed in terms of national interest in supporting allied states. $^{69}$ 
She worries elsewhere that in the current period of securitization, resettlement, in the US at least, may be vulnerable to targeted profiling. ${ }^{70}$ As Troeller cautions, expansion of resettlement must be developed in a way that "maintains its primacy as a protection tool and that it not be shaped in order to meet solely migration needs." 71

Australia, in contrast to Canada and the US, highlights a more sinister side of resettlement. Australia makes an intentional distinction between onshore asylum seekers and offshore refugees, and formally links the intake from the two categories. Refugee numbers are balanced in a way such that the offshore intake is reduced when onshore claimants increase. ${ }^{72}$ This scheme permits Australia the rhetoric of repeatedly labelling those who arrive on its shores as "queue jumpers" who compromise Australia's ability to help the "neediest" refugees still overseas. ${ }^{73}$ The essence of the argument, as put forth by Robert Illingworth, Assistant Secretary Onshore Protection Branch of the Refugee Humanitarian and International Division of Australia's Department of Immigration and Multicultural Affairs, is as follows:

Do we really want Australia's finite capacity to resettle those in need to be taken up on the basis of decisions of organized criminals about who they will ship to Australia? Or would we want to use as many places as possible to resettle those people identified as in greatest need of resettlement through coordinated international efforts under the UNHCR? ${ }^{74}$

The argument is as attractive as it is misleading. Australia is privileging resettlement over its obligation under the Refugee Convention of non-refoulement. ${ }^{75}$ Human Rights Watch has described Australia's system as an attempt to grant asylum "by invitation only."76 While Canada and the US may be using resettlement as a means of migrant selection under a humanitarian guise,${ }^{77}$ they are doing so in conjunction with the continued granting of inland/onshore asylum. Australia is attempting to do so in lieu of inland/onshore asylum. Nor does the scheme necessarily import order to the process. The Refugee Council of Australia found the Australian program to offer not "a place in a queue but a ticket in a lottery." 78 Moreover, the argument that the granting of inland asylum encourages smugglers, traffickers, or "organized criminals" has been solidly countered. It has been argued that in fact it is the "restrictive immigration policies in many industrialized States... [that] oblige economic migrants and refugees alike to use irregular channels" thereby stimulating the consequent growth in smuggling and trafficking. ${ }^{79}$ British philosopher Sir Michael Dummett has argued restrictive laws leave refugees with "no other way of escaping" and "the blame for the existence of these reviled traffickers in human beings lies largely with the governments that have erected the barriers the traffickers are helping people to circumvent." 80

The UK began a resettlement program in coordination with UNHCR in $2004 .{ }^{81}$ This immediately brought the UK within UNHCR's top ten resettlement countries. ${ }^{82}$ While encouraging new resettlement countries is in UNHCR's interest, the background dialogue underlying the UK's participation is troubling. In a vein similar to the Australian perspective, Jack Straw, while British Home Secretary, proclaimed in 1999 that the Refugee Convention was "no longer working as its framers intended," and suggested the European Union (EU) set up a program "under which an agreed number of refugees - and possible others in need of protection - would be identified in their own regions and brought to the EU for resettlement." ${ }^{33}$ In February 2002 the Labour Government issued a White Paper, Secure Borders, Safe Haven: Integration with Diversity in Modern Britain, which included a proposal to develop a resettlement program with the underlying intention that this would reduce asylum claims and remove the demand for smugglers. ${ }^{84}$

As noted above, the principle of non-refoulement is essential to refugee protection. The presumption of the Australian and British governments that inland claims can be replaced by comprehensive resettlement is in error. As is discussed further in the final section of this article, resettlement will never be comprehensive enough to absorb the world's refugees. Moreover, there will always be refugees with the means, creativity, or sheer daring to make impossible journeys and survive. The Tampa incident in Australia in 2001 and the hijacking and rerouting of an internal Ariana Airlines flight in Afghanistan to the UK in February 2000 are extreme examples of such measures. ${ }^{85}$ It is impossible to ever deter people completely from "exercising their human right to seek and enjoy asylum from persecution in another country." 86 However, as access to such asylum becomes more difficult to obtain, even the less overtly calculating approaches of Canada and the US to resettlement must be more carefully scrutinized.

\section{Fair Selection Models}

Assuming integration and repatriation whenever possible, it would be nice to imagine an ideal burden-sharing global refugee pie where all the world's remaining refugees were fairly parcelled out. The unfortunate reality is that there is neither the organization nor willingness to implement such a program, even if one were to support Schuck's model where countries could buy out of their obligations. ${ }^{87}$ David Martin of the Migration Policy Institute notes that " $[w]$ e are extremely unlikely in this new century to find the United States or any other country willing to make an open-ended 
commitment to resettlement of virtually all who escape a designated nation." 88 Former UNHCR High Commissioner Ruud Lubbers suggested a burden-sharing ratio of one refugee per 1,000 inhabitants. ${ }^{89}$ The suggestion, maintained by UNHCR as an annual resettlement quota of 0.1 per cent of a developed country's existing population, was greeted with silence by many governments. ${ }^{90}$ Fredriksson calculated that this ratio would have meant a 387 per cent increase in the 2002 resettlement targets of the US, already the most generous resettlement country. ${ }^{91}$ Yet, even with increased resettlement numbers there will always be the matter of selection.

If selections must be made, what is the best model on which to base the selections? Little appears to have been written in this area. Martin has prepared a comprehensive report on US resettlement reform published in 2005. While his recommendations are specifically directed to the US scheme, his overall message is broadly applicable. He recommends that the US resettlement program should not be

...limited to rescue from grave life-threatening dangers but will work actively to rescue displaced individuals and groups who face a wider range of harms, including the wastage of human potential that can result from protracted stay in a refugee camp....the program can still be prudent and selective in choosing among them, with full attention to countervailing factors such as possible magnet effects, other political impacts, and near term prospects for voluntary repatriation. ${ }^{92}$

In the Canadian context, Dauvergne, with Leonora Angeles and Agnes Huang, notes that men outnumber women in both Canada's domestic refugee determinations and in the government-assisted refugee resettlement category despite evidence that women make up about half of the refugees currently seeking protection internationally. ${ }^{93}$ While Canada cannot control for the dominance of men in the inland determination process, Dauvergne, Angeles, and Huang recommend that the Canadian government imprint a "somewhat crude equality measure" by ensuring "that women outnumber men in the government-assisted refugee category." 94

Fredriksson has proposed two, more international, models. He premises his proposals on the argument addressed above - that increased security measures and border enforcement following 11 September have had the consequent effect of reducing access to asylum. Fredriksson argues that "changing realities demand changed approaches." 95 He proposes two potential models to "create a coherent global system and...set in motion a transparent programme..." 96

The first model would be a formula-based approach factoring in length of time in an uncertain and non-durable situation and the likelihood and feasibility of repatriation in the foreseeable future. ${ }^{97}$ This is in line with UNHCR's official position on resettlement - that it is one of three durable solutions alongside local integration and repatriation. Martin sees the Agenda for Protection as further stressing this need to "widen the resettlement horizon to include refugees who might not be in immediate danger but for whom no other long-term solution is in sight." 98 The suggestion focuses resettlement on protracted refugee situations. UNHCR defines a protracted refugee situation as:

...one in which refugees find themselves in a long-lasting and intractable state of limbo. Their lives may not be at risk, but their basic rights and essential economic, social and psychological needs remain unfulfilled after years in exile. A refugee in this situation is often unable to break free from enforced reliance on external assistance. $^{99}$

UNHCR measures protracted situations as those in which refugee populations of 25,000 persons or more have been in exile in a developing country for five years or more. ${ }^{100} \mathrm{By}$ this calculation, UNHCR estimated that at the end of 2005 there were thirty-one different protracted situations in the world, accounting for some 5.2 million refugees. ${ }^{101}$

Resettlement should not be viewed as the presumed solution for refugees in protracted situations. Engagement is required with both the host country and the country of origin to ideally achieve local integration or repatriation. ${ }^{102}$ Loescher and Milner note that comprehensive solutions for protracted refugee situations "would employ the full range of possible solutions for refugees - repatriation and reintegration, local integration in the host country, and resettlement in a third country." 103 Only when circumstances make the other options unviable should resettlement be considered. A timeframe for determining other solutions to be unviable is, unfortunately, difficult and situation-specific. Troeller makes the suggestion that resettlement could be used as a "safety-valve" to assist countries of first asylum. ${ }^{104}$ This metaphor however fails to capture the essence of responsibility sharing as it suggests waiting until countries of first asylum reach a sort of boiling point before assistance is offered. Further, for 2005, UNHCR reported that the global number of refugees accepted for resettlement reached $80,800^{105}$ - barely over 1.5 per cent of the protracted numbers. These numbers are troublingly low. As Loescher and Milner indicate, there is an "increasingly dire lack of protection for millions of refugees."106 Thus, even supposing massive increases in the number of refugees countries are willing to accept for resettlement, eligibility would still require situation-specific evaluations and timeframe determinations, while the number of eligible refugees 
would presumably still demand further selection decisions. Fredriksson's first model therefore offers little real guidance on how resettlement refugees should be chosen.

As an alternative, Fredriksson suggests a second model in which resettlement need is defined on a group basis. Martin considers this the "key" to "enhancing the pace" of US resettlement expansion. ${ }^{107}$ In 2003 Canada piloted a group resettlement project in which individual assessments were bypassed with 780 Sudanese and Somali refugees from Kenyan refugee camps. Approximately 1,000 Afghans came from Central Asia under the same program in 2004 and 810 Burmese refugees from Thailand were resettled over fall 2006 and early 2007. ${ }^{108}$ Since 2004, UNHCR has submitted thirteen refugee groups (43,000 refugees) for resettlement consideration from asylum countries in Africa, the Middle East, and Central and Eastern Asia. ${ }^{109}$ The theory behind the new system for group resettlement is that it will reduce processing time and create ready-made support systems for arriving refugees.

The question raised by the Canadian project is how these groups are selected. While these groups are undeniably deserving refugees, why were they chosen over other equally deserving groups? The concern, often heard in the American context, is that resettlement is too greatly influenced by interest groups. ${ }^{110}$ Adding to the concerns, Savitri Taylor notes:

The problem with relying on situation-specific agreements being negotiated on an ad hoc basis is that success is made dependent on the existence of a political will to undertake each specific exercise. As the Assistant High Commissioner has noted, "comprehensive arrangements have not been always pursued even for refugee situations that warranted them." While it makes sense to negotiate situation-specific agreements in the shortterm where the political will clearly exists, doing so should not be a substitute for the long-term goal of negotiating a non-situation specific multilateral agreement on responsibility-sharing. ${ }^{111}$

The model is also extremely susceptible to the modes of abuse voiced by van Selm and Troeller. As Taylor notes, though, this is not to say this model should be discarded. Effective processing that makes resettlement more attractive and affordable to the receiving countries should be encouraged in the hopes of encouraging the acceptance of increased numbers. What is currently lacking is a transparent and systematic structure for group selection.

A further model, not noted by Fredriksson, is need-based acceptance. Rather than addressing the "profound wastage of human lives" noted by Martin in protracted situations, need-based criteria target specific refugee types. UNHCR's resettlement criteria focus on eight elements: legal and physical protection needs, medical needs, survivors of violence and torture, women-at-risk, family reunification, children and adolescents, elderly refugees, and refugees without local integration prospects. ${ }^{112}$ From UNHCR's global position, urgent need-based resettlement becomes a juggling act - looking at refugees and determining which country, each with distinct priorities and claim processes, will be the most likely to take an individual. In contrast to group resettlement, this model lends itself to detailed individual assessments of need.113

These differing models, all well-intentioned and highlighting valid areas of resettlement need, return us to resettlement's schizophrenic dilemma. The solution, I submit, is a top-down approach coming from UNHCR that acknowledges the validity of all of the above models. This acknowledgement should come through operational guidelines and criteria for each type of resettlement that as Fredriksson laments "are now virtually absent from the UNHCR Resettlement Handbook."114 The percentage of resettlement from protracted situations should be established as well as whether all or some of protracted resettlement should be through group resettlement - a sort of melding of Fredriksson's models. UNHCR's need-based resettlement is already well-structured but should not be privileged in a way that relegates protracted and group resettlement to ad hoc secondary arrangements. The two models should be running parallel with states encouraged to take in refugees from both streams and clear processes for how to do so. The "crude equality measure" proposed by Dauvergne, Angeles, and Huang should likewise be transposed to the international scheme. Nothing in these models would prevent situation-specific considerations of whether resettlement is appropriate. All these models can be intermingled and combined in a complementary manner. What is needed is transparent planning and coordination from UNHCR.

UNHCR should likewise be more vocal in encouraging not just resettlement but resettlement quotas correlated to population density, gross domestic product, or some other agreed standard. While UNHCR cannot oblige states to take on their recommended numbers, a more emphatic statement by UNHCR would at least serve to highlight the low current resettlement numbers, even by the traditional resettlement countries. Further, more direction from UNHCR on resettlement distribution could lead to an increased willingness by states, and their citizens, for greater refugee resettlement. Gibney argues that "[a] well-publicized and transparent system for dealing with refugee burdens could only add to the legitimacy of international arrangements for protecting refugees..."115 Van Selm adds that resettlement, once started, “has a 'knock on' effect - 
meaning that the public gets more information and understands more about the situations from which both resettled refugees and asylum seekers have fled." 116 From the perspective of cost analysis, an issue not explored here but highly relevant, Loescher highlights that "international cooperation and collective action through resettlement sharing" would enable "clarity, consistency and lower transaction costs" for states. ${ }^{117}$

\section{Conclusion}

In concluding, I offer six recommendations based on the above analysis. The recommendations are intended to initiate dialogue leading to a comprehensive resettlement model. Actors from several sides can aid visibility, promote real change, and increase resettlement numbers. In addition to UNHCR, national governments, academics, and activists can prompt action. The recommendations that follow are therefore directed either generally at these four groups or, when specified, to individual actors.

\section{Recommendations}

1. Resettlement and non-refoulement must be complementary tools of protection. There is no refugee queue and only one door. Images and allusions to queue-jumping and entrance through the back door are misleading and detrimental to responsible protection. Both resettlement and non-refoulement are imperfect but necessary protection tools. Any increased focus on resettlement must not be in exchange for reduced access to asylum or an abandonment of the commitment to non-refoulement.

2. Global resettlement numbers should be increased. The "tyranny of geography" and locational (dis)advantage mean that certain countries are unfairly bearing the responsibility for the majority of refugee flows, counter to the commitment in the Refugee Convention to burden sharing. Heightened securitization in the face of increased terrorist threats since 2001 has concomitantly reduced access to Western states. It is therefore becoming increasingly difficult for asylum seekers to reach safe states and trigger the legal obligation of non-refoulement. Legally legitimate reductions of asylum claims through increased border monitoring add force to the argument that resettlement numbers should be increased to combat unfair and often crippling refugee distribution.

3. UNHCR should set and encourage resettlement quotas correlated to some agreed standard. The current absence of any recognized resettlement quota is unacceptable. A clear statement by UNHCR on ideal resettlement distribution, be it by population density, gross domestic product, or some combination of measurements, would draw attention to the reality that the traditional resettlement countries, in fact, resettle very few refugees. While UNHCR cannot enforce increases, more direction may convince states, and their citizens, to undertake greater refugee resettlement.

4. Resettlement selection must reflect refugee protection and not national interests. The appeal of resettlement is often tied to a nation's notion that it offers a degree of control over refugee protection in contrast to the unpredictable nature of non-refoulement. Unlike the obligation imposed by non-refoulement to accept those who arrive at the state's "door," resettlement provides the ability to select for whom the "door" will be opened. While selection is an unavoidable aspect of resettlement, mechanisms must be in place to ensure that selection is committed to refugee needs and not a nation's interest in selecting the "best" refugees - the healthiest, most educated, most compatible, most similar to regular and desirable immigrants.

5. UNHCR should design a top-down model and operational guidelines for resettlement selection. While UNHCR cannot force compliance with its recommendations, it can and should provide a more comprehensive model and operational guidelines to which states can choose to subscribe. The appeal of such a structure is the simplicity, consistency and transparency of selection, reducing the scope for criticism, political influence and corruption. Moreover, such a model would provide a measure against which states could gauge their current selections and recognize gaps in their schemes.

6. A resettlement model should incorporate need-based, protracted, and group resettlement. UNHCR currently focuses resettlement on eight need-based criteria. While ideal for urgent and priority cases, the criteria fail to provide a comprehensive resettlement scheme. In addition to urgent need situations, protracted refugee groups exist in everworsening and volatile conditions of limbo that must be addressed. Group resettlement that reduces processing time and creates ready-made support systems for arriving refugees deserves increased attention and coordination. A resettlement model should incorporate both need-based and protracted resettlement, the latter through group processing.

UNHCR recognizes the need for the type of resettlement scheme proposed herein. Two goals of the Agenda for Protection are for "States that offer resettlement opportunities to consider increasing their resettlement quotas, diversifying their intake of refugee groups, and introducing more flexible resettlement criteria," 118 and for "States and UNHCR to explore the feasibility of establishing a central biometric registration system to support the identification of refugees in need of resettlement." 119 This article can hopefully add to the dialogue that will bring these goals closer to reality. 


\section{Notes}

1. Convention relating to the Status of Refugees, 28 July 1951, 189 U.N.T.S. 150 (entered into force 22 April 1954) at art. 1A [Refugee Convention].

2. Ibid. at art. 33(1).

3. Statute of the United Nations High Commissioner for Refugees, UNGA A/RES/248, 14 December 1950, s.1.

4. UNHCR, Resettlement Handbook (November 2004) at 1/2, online: <http://www.unhcr.org/protect/3d4545984.html>.

5. On a page titled "Protecting Refugees" on its Web site, UNHCR notes that "The main global treaty for the protection of refugees - the UN Convention relating to the Status of Refugees - marked its $50^{\text {th }}$ anniversary on 28 July 2001 amid concerns that some of its key provisions are being questioned and even openly flouted by a growing number of states," online: <http://www.unhcr.org/cgibin/texis/vtx/protect?id $=3 \mathrm{c} 0794574>$. In a recent statistical report UNHCR further noted that violations of the core principle of non-refoulement were reported by 50 per cent of UNHCR's country offices in 2005 and that 75 per cent of the states in possible breach of the principle are signatories to the Refugee Convention or 1967 Protocol (infra note 27) or both. UNHCR, Measuring Protection by Numbers 2005 (November 2006) at 11, online: $<$ http://www.unhcr.org/statistics $>$ [Measuring Protection].

6. First Track: "Ministerial Meeting of States Parties" (12 and 13 December 2001), online: <http://www.unhcr.org/protect/PROTECTION/3b9490a54.html>; Second Track: Erika Feller, Volker Türk, and Frances Nicholson, eds., Refugee Protection in International Law: UNHCR's Global Consultations on International Protection (Cambridge: Cambridge University Press, 2003), online: <http://www.unhcr.org/protect/PROTECTION/3b94e7a2a.html>; Third Track: "Executive Committee Meetings", online <http://www.unhcr.org/protect/ PROTECTION/3b95d8d17.html $>$.

7. United Nations, Agenda for Protection, A/AC. 96/965/Add. 1, General Assembly, Executive Committee of the High Commissioner's Programme (26 June 2002) $3^{\text {rd }}$ ed., October 2003 [Agenda for Protection].

8. Resettlement Handbook, supra note 4 at $1 / 2$.

9. This statement belies the complexity of resettlement decisions that are explored in the substance of this article.

10. In the 1990s James C. Hathaway and Alexander Neve and, separately, Peter Schuck proposed temporary protection regimes as a means to encourage states to accept greater refugee numbers while deterring false claims. James C. Hathaway and R. Alexander Neve, "Making International Refugee Law Relevant Again: A Proposal for Collectivized and Solution-Oriented Protection" (1997) 10 Harv. Hum. Rts. J. 115; Peter H. Schuck, "Refugee Burden-Sharing: A Modest Proposal" (1997) 22 Yale J. Int'l. L. 243. See also James C. Hathaway, "Book Review: Rethinking Refugee Law” (2004) 98 Am. J. Int'l. L. 616 at 617.

11. I take this term from the Canadian resettlement program where "government-assisted refugees" is used to describe refugees resettled through the Canadian government resettlement program in contrast to private sponsorship.
12. Dennis Gallagher, "The Evolution of the International Refugee System” (1989) 23:2 International Migration Review 579 at 579 .

13. James C. Hathaway, The Rights of Refugees under International Law (Cambridge \& New York: Cambridge University Press, 2005) at 964 [Hathaway, Rights of Refugees].

14. Ibid.

15. Gary Troeller, "UNHCR Resettlement: Evolution and Future Direction” (2002) 14:1 Int'l J. Refugee L. 85 at 87 [Troeller].

16. Ibid. at 88 .

17. Ibid. at 85 and 89.

18. Global Consultations on International Protection, Strengthening and Expanding Resettlement Today: Challenges and Opportunities, $4^{\text {th }}$ Mtg., EC/GC/02/7 (25 April 2002) at para. 5.

19. Measuring Protection, supra note 5 at 1.

20. Ibid.

21. UNHCR, 2005 Global Refugee Trends (Geneva: UNHCR, 2006) at 3, online: $<$ http://www.unhcr.org/statistics.html $>$.

22. View of the former Indian permanent representative to the United Nations at the forty-eighth Session of the UNHCR Executive Committee, cited in Brian Gorlick, "Refugee Protection in Troubled Times" [Gorlick] in Niklaus Steiner, Mark Gibney, and Gil Loescher, eds., Problems of Protection: The UNHCR, Refugees and Human Rights (New York \& London: Routledge, 2003) 79 at 81.

23. Matthew J. Gibney, The Ethics and Politics of Asylum: Liberal Democracy and the Response to Refugees (Cambridge: Cambridge University Press, 2004) at 195 [Gibney].

24. Even this terminology has its drawbacks. Savitri Taylor notes " $\mathrm{t}]$ he choice of terminology describing the obligation as 'responsibility-sharing' rather than 'burden-sharing' is deliberate. As others have pointed out, whether asylum seekers are a burden or benefit depends, among other things, on the time frame adopted." Savitri Taylor, "The Pacific Solution or a Pacific Nightmare?: The Difference between Burden Shifting and Responsibility Sharing" (2005) 6 Asian Pac. L. \& Pol'y J. 1 at 39 [Taylor].

25. Supra note 23 at 246.

26. Supra note 1.

27. Protocol relating to the Status of Refugees, 1967, 606 UNTS 267 (entered into force 4 October 1967) [1967 Protocol].

28. As at 10 December 2006, contributions to UNHCR programs for the budget year 2006 totaled US $\$ 1,031,016,510$ from governments and private donors. UNHCR, "Donors/Partners," online: <http://www.unhcr.org/partners/3b963b874.html>.

29. Schuck, supra note 10. Mary Crock provides a helpful summary of Schuck's proposal and the consequent criticisms in "In the Wake of the Tampa: Conflicting Visions of International Refugee Law in the Management of Refugee Flows" (2003) 12 Pac. Rim. L. \& Pol'y J. 49 at 80 [Crock]:

Peter Schuck has argued for the introduction of a quota system whereby non-refugee producing states would be allocated a certain number of refugees for care or resettlement each year. This quota would be determined after establishing a global figure of the number of refugees in 
need of protection each year, and would be allocated in a manner proportionate to the wealth and carrying capacity of a nation. The essence of Schuck's proposal is that developed states should then be able to elect either to take in their allocation of refugees or pay other states to take in or care for the specified number. Put another way, Shuck [Schuck] proposes that a state should be able to subrogate its liability by approaching other states to accept its refugee quota in exchange for cash, and/or other incentives such as "credit, commodities, development assistance, technical advice, weapons and political support." [footnotes omitted].

And at 85:

After publishing his "modest proposal," Shuck [Schuck] met with pointed criticisms from fellow academics Deborah Anker, Joan Fitzpatrick, and Andrew Schaknove. The three argue that the Shuck [Schuck] model would degrade the Refugee Convention as a human rights instrument. By turning the plight of refugees into an economic bargaining tool, wealthy states would be able to take advantage of poorer states, forcing them to shoulder the burden of caring for refugees in circumstances where they are likely to suffer in both the short and long terms. The authors argue that "by emphasizing the temporary nature of physical asylum and conferring it through voluntary coalitions of states, the economic and social rights of refugees under the Refugee Convention and Protocol will be de-emphasized." [footnotes omitted].

30. Supra note 7 at 61.

31. UNHCR, "States Parties to the Convention and the Protocol" (1 December 2006), online: <http://www.unhcr.org/cgibin/texis/vtx/protect?id=3c0762ea4> ["UNHCR States Parties"]. One-hundred forty countries have acceded to both the Refugee Convention and 1967 Protocol. The accession of Montenegro to both the Refugee Convention and 1967 Protocol in October 2006 is the most recent as of 1 December 2006.

32. UNHCR, "Refugees by Numbers 2006 edition," online: $<$ http://www.unhcr.org/basics/BASICS/3b028097c.html\#Re settlement $>$ ["Refugees by Numbers"].

33. Gil Loescher and James Milner, "Protracted Refugee Situations: Domestic and International Security Implications" (2005) 45:375 Adelphi Papers 7 at 74-75 [Loescher and Milner].

34. Bill Frelick, "Rethinking US Refugee Admissions: Quantity and Quality" (2002) World Refugee Survey 28 at 35, cited in David A. Martin, The United States Refugee Admissions Program: Reforms for a New Era of Refugee Resettlement (Washington, DC: Migration Policy Institute, 2005) at 11 [Martin].

35. Jennifer Hyndman, Managing Displacement: Refugees and the Politics of Humanitarianism (Minneapolis: University of Minnesota Press, 2000) at 190.

36. Gil Loescher, "UNHCR at Fifty: Refugee Protection and World Politics" in Steiner, Gibney, and Loescher, supra note 22,3 at 13 [Loescher, "UNHCR at Fifty"].

37. Supra note 35 at 24 [footnote omitted].

38. Loescher, "UNHCR at Fifty," supra note 36 at 13.

39. Ibid. at 14 .
40. Arthur C. Helton, "What Is Refugee Protection? A Question Revisited" in Steiner, Gibney, and Loescher, supra note 22, 19 at 30. See also Beth Elise Whitaker, "Changing Priorities in Refugee Protection: The Rwandan Repatriation from Tanzania" in Steiner, Gibney, and Loescher, ibid. at 141-154.

41. Janet Dench, "Controlling the Borders: C-31 and Interdiction" (2001) 19:4 Refuge 34 at 34.

42. Supra note 40 at 31 .

43. Volker Türk and Frances Nicholson, "Refugee Protection in International Law: An Overall Perspective" [Türk and Nicholson] in Feller, Türk \& Nicholson, supra note 6, 1 at 5.

44. Catherine Dauvergne, "Sovereignty, Migration and the Rule of Law in Global Times" (2004) 67:4 Mod. L. Rev. 588 at 588 [Dauvergne, "Sovereignty"].

45. Article 31 states:

1) The Contracting States shall not impose penalties, on account of their illegal entry or presence, on refugees who, coming directly from a territory where their life or freedom was threatened in the sense of article 1, enter or are present in their territory without authorization, provided they present themselves without delay to the authorities and show good cause for their illegal entry or presence.

2) The Contracting States shall not apply to the movements of such refugees restrictions other than those which are necessary and such restrictions shall only be applied until their status in the country is regularized or they obtain admission into another country. The Contracting States shall allow such refugees a reasonable period and all the necessary facilities to obtain admission into another country.

Franck Düvell writes that " $t]$ he political processes of nation building... defined the extent of a state's territory, its national borders, national space, and so nationality and membership were reconstructed, and deserving and undeserving individuals defined and members created." Franck Düvell, "The Irregular Migration Dilemma: Keeping Control, Out of Control or Regaining Control?” in Franck Düvell, ed., Illegal Immigration in Europe: Beyond Control? (New York: Palgrave Macmillan, 2006) 3 at 24.

46. Agenda for Protection, supra note 7 at 46.

47. Measuring Protection, supra note 5 at 2.

48. See Dauvergne, "Sovereignty," supra note 44 at 600.

49. Troeller, supra note 15 at 92.

50. John Fredriksson, "Reinvigorating Resettlement: Changing Realities Demand Changed Approaches” (2002) 13 Forced Migration Review 28 at 28 [Fredriksson].

51. Joanne van Selm, "Refugee Protection in Europe and the U.S. after 9/11" in Steiner, Gibney, and Loescher supra note 22, 237 at 239 [Van Selm, "Refugee Protection after 9/11"].

52. Hathaway, Rights of Refugees, supra note 13 at 964.

53. Measuring Protection, supra note 5 at 19.

54. Ibid. UNHCR provides data on resettlement through its own referrals. By these numbers, in 2005, the US received 23,289 cases for resettlement, Canada 5,811, Australia 5,117, and Sweden 1,190 . UNHCR notes, however, that according to

(C) Shauna Labman, 2007. This open-access work is licensed under a Creative Commons Attribution-NonCommercial 4.0 International License, which permits use, reproduction and distribution in any medium for non-commercial purposes, provided the original author(s) are credited and the original publication in Refuge: Canada's Journal on Refugees is cited. 
government sources Australia provides some 13,000 resettlement places annually and the US received a total of 52,000 individuals under its resettlement program during 2005 and Canada 10,400 persons.

55. "Part 8: The NGO Perspective Global Consultations on International Protection Third Track, Theme 3: The Search for Protection-Based Solutions: NGO Statement on Resettlement (22-24 May 2002)” 22:2/3 Refugee Survey Quarterly (2003) 432 at 433.

56. In 2005 the UK was listed by UNHCR as the tenth highest resettlement country with a mere 242 persons received. Measuring Protection, supra note 5 at 19.

57. See Catherine Dauvergne, Humanitarianism, Identity and $\mathrm{Na}$ tion: Migration Laws in Canada and Australia (Vancouver: University of British Columbia Press, 2005) at 93 [Dauvergne, Humanitarianism, Identity and Nation].

58. Government of Canada, "Country Chapter: CANADA" in Resettlement Handbook, supra note 4 at 1.

59. Immigration and Refugee Protection Act, S.C. 2001 c. 27; Immigration and Refugee Protection Regulations, SOR/2002-227, s.139(1)(g) "successfully established" and s.139(2) "vulnerable," "urgent need".

60. Michael Casasola, "Current Trends and New Challenges for Canada's Resettlement Program” (2001) 19:4 Refuge 76 at 77 [Casasola].

61. Ibid.

62. Canadian Council for Refugees, First Annual Report Card on Canada's Refugee and Immigration Programs (November 2003), online: <http://www.web.net/ ccr/reportcard2003. htm>.

63. Ibid.

64. Department of Foreign Affairs and International Trade, "Canada's Actions since the September 11 Attacks Fighting Terrorism - A Top Priority," cited in Erin Kruger, Marlene Mulder, and Bojan Korenic, "Canada after 11 September: Security Measures and 'Preferred' Immigrants” (2004) 15:4 Mediterranean Quarterly 72 at 77.

65. Bill C-31 was first tabled in April 2000 but died when Parliament was dissolved later that year. Amended legislation, Bill C-11, was introduced and passed in November 2001.

66. Casasola, supra note 60 at 79. When tabling Bill C-31 on 6 April 2000, then Minister of Citizenship and Immigration Elinor Caplan stated, "Closing the back door to those who would abuse the system allows us to ensure that the front door will remain open." Citizenship and Immigration Canada, News Release 2000-09, "Caplan Tables New Immigration and Refugee Protection Act” (6 April 2000), online: <http://www. cic.gc.ca/english/press/00/0009-pre.html>.

67. Gibney, supra note 23 at 159.

68. Ibid. at 160.

69. Joanne van Selm, "Refugee Protection Policies and Security Issues" in Edward Newman and Joanne van Selm, eds., Refugees and Forced Displacement: International Security, Human Vulnerability, and the State (Tokyo, New York, \& Paris: United Nations University Press, 2003) 66 at 69.
70. Van Selm, "Refugee Protection after 9/11," supra note 51 at 258.

71. Troeller, supra note 15 at 93.

72. For a more detailed discussion of Australia's policy see Dauvergne, Humanitarianism, Identity and Nation, supra note 57 at 92 , note 30 .

73. Ibid. at 92, note 31. See also William Maley, "Receiving Afghanistan's Asylum Seekers: Australia, the Tampa 'Crisis' and Refugee Protection” (2002) 13 Forced Migration Review 19 at 20 [Maley].

74. Robert Illingworth, "Durable Solutions: Refugee Status Determination and the Framework of International Protection" in Susan Kneebone, ed., The Refugee Convention 50 Years On: Globalisation and International Law (Aldershots, Hants, England \& Burlington, VT: Ashgate, 2003) 91 at 105.

75. Australia ratified the Refugee Convention in 1954 and the 1967 Protocol in 1973. "UNHCR States Parties," supra note 31.

76. Human Rights Watch, "By Invitation Only: Australian Asylum Policy” (2002) 14:10(C) Human Rights Watch, online: <http://hrw.org/reports/2002/australia/>.

77. While comparing Canadian and Australian refugee policies in Humanitarianism, Identity and Nation, supra note 57, Dauvergne, who earlier refers to humanitarianism as a "self-serving ruse," goes on to write: "Canada's law is filled with humanitarianism . . . demonstrating . . . that being perceived as humanitarian is vital" at 74 and 218.

78. Refugee Council of Australia, The Size and Composition of the 2000-2001 Humanitarian Program: Views from the Community Sector (Refugee Council of Australia, 2000) at 53 cited in Maley, supra note 73 at 20.

79. Türk and Nicholson, supra note 43 at 5.

80. Michael Dummett, On Immigration and Refugees (New York \& London: Routledge, 2001) at 44, cited in Maley, supra note 73 at 20.

81. Refugee Council, "UK Refugee Resettlement Programme Begins" (23 March 2004), online: <http://www.refugeecouncil. org.uk/news/press/2004/march/20040323 ukre.htm>.

82. Measuring Protection, supra note 5 at 19.

83. Jack Straw, "An Effective Protection Regime for the Twenty-first Century" (Speech at the Institute for Public Policy Research, London, 6 February 2001), cited in Gorlick, supra note 22 at 80.

84. David Blunkett, Home Secretary, Secure Borders, Safe Haven: Integration with Diversity in Modern Britain, (White Paper) (Crown Copyright, 2001), online: $<\mathrm{http}: / / \mathrm{www}$.archive2.officialdcuments.co.uk/document/cm53/5387/cm5387.htm>.

85. The Tampa incident refers to the rescue of 433 mostly Afghan asylum seekers from a sinking boat by the Norwegian freighter Tampa in August 2001. See Taylor, supra note 24, and Crock, supra note 29. In February 2000 a domestic Ariana Airlines flight within Afghanistan was hijacked and rerouted to the UK where asylum applications were filed by seventy-eight of the passengers on board. See "Government Appeal over Hijackers” BBC (11 May 2006), online: <http:// news.bbc.co.uk/ 2/hi/uk_news/politics/4760873.stm >. 
86. Van Selm, "Refugee Protection after 9/11," supra note 51 at 254. The quotation is an allusion to Article 14(1) of the UniversalDeclaration of Human Rights, GA Res. 217 (III), UN GAOR, 3d Sess., Supp. No.13, UN Doc. A/810 (1948), which provides, "Everyone has the right to seek and to enjoy in other countries asylum from persecution."

87. See Schuck, supra note 10 and Crock, supra note 29.

88. Martin, supra note 34 at 8.

89. See Fredriksson, supra note 50 at 31.

90. Ibid.; Troeller, supra note 15 at 93 .

91. Ibid.

92. Martin, supra note 34 at 119.

93. Catherine Dauvergne, Leonora C. Angeles, and Agnes Huang, Gendering Canada's Refugee Process (Ottawa: Status of Women Canada, 2006) at 51.

94. Ibid.

95. Fredriksson, supra note 50 at 28.

96. Ibid. at 31

97. Ibid. at 30 .

98. Martin, supra note 34 at 98.

99. Executive Committee of the High Commissioner's Programme, Protracted Refugee Situations, 30 ${ }^{\text {th }}$ Mtg., EC/54/ SC/CRP.14 (10 June 2004) at para. 3. For a comprehensive discussion of the challenges and security concerns associated with protracted refugee situations see Loescher and Milner, supra note 33.

100. UNHCR numbers exclude Palestinian refugees who fall under the separate mandate of the United Nations Relief and Works Agency for Palestine Refugees in the Near East (UNRWA).

101. Measuring Protection, supra note 5 at 18.

102. Loescher and Milner, supra note 33 at 19-20. Loescher and Milner argue, at 20, that " $\mathrm{t}]$ he primary causes of protracted refugee situations are to be found in the failure of major powers, including the US and the EU, to engage in countries of origin and the failure to consolidate peace agreements....Assistance to long-term refugee populations through humanitarian agencies is no substitute for sustained political and strategic action."

103. Ibid. at 71 .

104. Troeller, supra note 15 at 93.

105. "Refugees by Numbers," supra note 32.

106. Loescher and Milner, supra note 33 at 71.

107. Martin, supra note 34 at 26.

108. Citizenship and Immigration Canada, News Release 2006-04, "Canada's New Government Welcomes Burmese Refugees” (20 June 2006), online: <http://www.cic.gc.ca/ english/press/06/0604-e.html>.

109. Measuring Protection, supra note 5 at 19.

110. Martin, supra note 34 at 11; Gibney, supra note 23 at 132.

111. Taylor, supra note 24 at 39.

112. Resettlement Handbook, supra note 4 at c.3.

113. See Resettlement Handbook, ibid. at c. 6 for the steps involved in the assessment and preparation of a resettlement submission.

114. Fredriksson, supra note 50 at 30.

115. Gibney, supra note 23 at 246.

116. Joanne van Selm, "The Strategic Use of Resettlement" (Paper presented at the International Seminar "Towards More Orderly and Managed Entry in the EU of Persons in Need of International Protection," Rome 13-14 October 2003), at 3-4, online: <http://www.migrationpolicy.org/pubs/2003.php >.

117. Gil Loescher, The UNHCR and World Politics: A Perilous Path (Oxford: Oxford University Press, 2001) at 367.

118. Agenda for Protection, supra note 7 at 80, Goal 5(5).

119. Agenda for Protection, ibid., Goal 5(6).

Shauna Labman is a Ph.D. student at the University of British Columbia, Faculty of Law, and a member of the Law Society of Upper Canada. 